\title{
ОКРЕМІ ГОСПОДАРСЬКИ КОРИСНІ ОЗНАКИ БДЖІЛ РІЗНИХ ГЕНЕАЛОГІЧНИХ ФОРМУВАНЬ КАРПАТСЬКӦ̈ ПОРОДИ
}

\author{
Федорович Віталій Васильович \\ доктор сільськогосподарських наук, старший науковий співробітник \\ Інститут біології тварин НАAН \\ ORCID: 0000-0002-4272-4045 \\ E-mail: lionel@i.ua
}

Петько Марія Сергіївна аспірант Інститут розведення і генетики тварин НААН ім. М.В. Зубця; ORCID: 0000-0002-5375-7889 E-mail: pmarichka777@gmail.com

Чорний Ігор Олександрович асистент Подільський державний аграрно-технічний університет ORCID: 0000-0003-2161-4098 E-mail: chorniyigor78@gmail.com

Мазур Наталія Петрівна доктор сільськогосподарських наук Інститут біології тварин НААН ORCID: 0000-0001-6244-713X

E-mail: BabikN@i.ua

Серед фракторів, що зумовлюють прогрес людства, значне місце належить селекції племінних і продуктивних якостей бджіл. Можливості підвищення продуктивності та життєздатності бджолиних сімей шляхом покращення їх спадкових задатків залежить від того, наскільки добре вивчення питання еволюції та біології бджоли. При цьому, слід відмітити, що важливу роль у підвищенні продуктивності пасік має використання міжпородних та міжлінійних гібридів. 3 огляду на зазначене, метою досліджень було оцінити миролюбивість, варростійкість, силу, зимостійкість та гігієнічні властивості бджолиних сімей різних внутрішньолінійних кросів карпатської популяції бджіл. Дослідження проведені на бджолах різних генеалогічних формувань карпатської породи у приватних пасіках в с. Наварія та м. Броди Львівської області. Для проведення експериментальних досліджень було сформовано 6 груп по 10 бджолосімей у кожній: I - контрольна група - місцеві бджоли карпатської популящії (тип «Вучківський» - 10 бджолосімей); II - дослідна група - інбредна

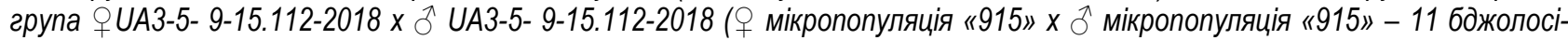

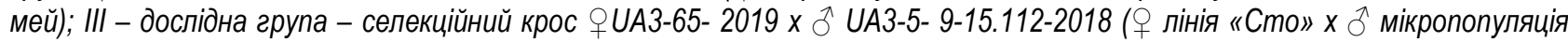
«915» - 10 бджолосімей; IV - дослідна група - селекційний крос ㅇ UA3-5- 35-2019 х § UA3-5- 9-15.112-2018 († Вучківська х

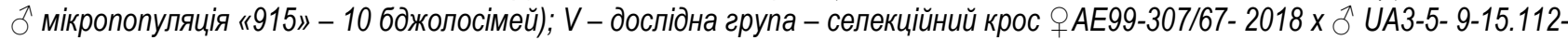
2018 ( лінія «Тройзек 07» x §̊ мікропопуляція «915» - 10 бджолосімей); VI - дослідна група - селекційний крос $+\mathrm{G}$. Macha

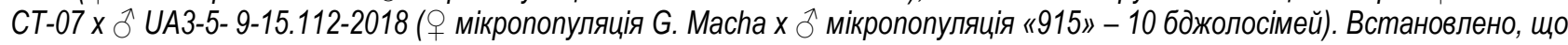
між бджолами різних внутрішньопородних кросів карпатської популяції спостерігалися певні відмінності за показниками відходу бджіл, загальних витрат кормів за зимівлю та в розрахунку на 1 ке бджіл. Найменше корму за зиму спожили бджолосім'ї шостої групи, проте в розрахунку на 1 ка бджіл найнижчі результати відмічені у бджіл третьої групи. Кращою зимостійкістю характеризувалися бджоли, отримані від поєднання самок і самців мікропопуляції «915», а гігієнічною поведінкою через 12 і 24 годин після пошкодження розплоду - бджолосім'ї другої і п'ятої груп відповідно. За стійкістю до варроатозу кращими виявилися бджоли селекційного кросу Ф UA3-65- 2019 х § UA3-5- 9-15.112-2018. Найбільш сильними перед зимівлею були бджолосім'ї інбредного кросу мікропопуляції «915», а найслабшими - бджолосім'ї кросу G. Масһа. Більшість кросів відносилися до спокійних миролюбних і лише бджолосім'ї місцевої карпатської популяції та кросу ф ЧАЗ5- 35-2019 х §ิ UАЗ-5- 9-15.112-2018 відзначалися злобливістю.

Ключові слова: Карпатська порода бджіл, міжлінійні кроси, варростійкість, гігієнічна поведінка, сила бджолосімей, миролюбність бджіл, зимостійкість бджолосімей.

DOI: https://doi.org/10.32845/bsnau.Ivst.2020.4.12

Сучасне сільськогосподарське виробництво неможливе без галузі бджільництва. Скрізь, де вирощують соняшник, гречку, ріпак, коріандр, кормові бобові, овочеві культури, у садах, на городах, під склом теплиць, на квітках комахозапилюваних рослин працюють бджоли. Крім того, від

бджіл людина одержує цінні продукти, рівнозначних замінників яким немає. Це насамперед мед, віск, квітковий пилок (обніжжя, перга), прополіс, маточне молочко, бджолина отрута. За обсягом виробництва меду Україна посідає перше місце в Європі, і п'яте в світі, офріційно виробляючи май- 
же 70 тис. тонн меду, втім самі виробники наводять цифру у понад 100 тис. тонн, що становить 5-6 \% світового виробництва. За виробництвом цього продукту наша країна посідає третє місце серед світових експортерів, поступаючись лише Китаю та Аргентині $[1,7]$.

Відповідно до природно-кліматичних і медозбірних умов в Україні сформувалися і набули значного поширення три породи бджіл: українська, карпатська, середньоросійська (поліська популяція). Карпатська порода бджіл за останні 50 років набула небаченого раніше поширення. Сім'ї цих бджіл швидко розвиваються навесні і в травні досягають повної сили та дають багато меду. Бджолярі звертають увагу на нерійливість карпатських бджіл. Місцеві карпатські бджоли добре пристосувались до існування в умовах суворого клімату, тому їм властиві досить висока зимостійкість, бурхливий весняний розвиток та активна робота в умовах гір на медоносах з малим вмістом цукру в нектарі. Вони здатні збирати нектар з вмістом цукру 8-9 \% [5, 6, 9,10, 14].

Багатьма дослідженнями доведено, що з метою підвищення продуктивності бджіл в кожній природнокліматичній зоні необхідно використовувати пристосовані до місцевих умов типи та лінії бджіл, між якими може відбуватися обмін генетичними ресурсами. У одержаних нащадків наступних поколінь необхідно всесторонньо оцінювати і виявляти комбінаційні здатності 3 метою визначення їх значення у регіональних системах розведення медоносних бджіл $[4,8,13,15]$.

3 огляду на зазначене, метою наших досліджень було оцінити миролюбивість, варростійкість, силу, зимостійкість та гігієнічні властивості бджолиних сімей різних внутрішньолінійних кросів карпатської популяції бджіл.

Матеріали та методи досліджень.

Дослідження проведені на бджолах різних генеалогічних формувань карпатської породи у приватних пасіках в С. Наварія Львівської області.

Для проведення експериментальних досліджень було сформовано 6 груп по 10 бджолосімей у кожній:

I - контрольна група - місцеві бджоли карпатської популяції (тип «Вучківський» - 10 бджолосімей).

II - дослідна група - інбредна група фUA3-5- 915.112-2018 x के UA3-5- 9-15.112-2018 ( мікропопуляція «915» х ठૈ мікропопуляція «915»-11 бджолосімей).

III - дослідна група - селекційний крос qUA3-652019 x ठै UA3-5- 9-15.112-2018 ( лінія «Сто» x के мікропопуляція «915» - 10 бджолосімей).

IV - дослідна група - селекційний крос фUA3-5- 35-

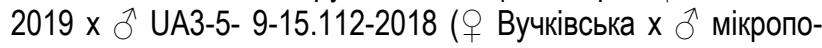
пуляція «915» - 10 бджолосімей).

V - дослідна група - селекційний крос ФAE99307/67- 2018 x ठे UA3-5- 9-15.112-2018 (q лінія «Тройзек 07» x ふૈ мікропопуляція «915» - 10 бджолосімей).

VI - дослідна група - селекційний крос $\bigcirc \mathrm{G}$. Macha CT-07 x § UA3-5- 9-15.112-2018 (૧ мікропопуляція G. Macha x ठै мікропопуляція «915»-10 бджолосімей).

Силу бджолиних сімей під час весняного розвитку визначали за кількістю вуличок. В одній вуличці стандартного стільника розміщується 2000-2500 робочих бджіл. У випадках, коли бджоли обсиджують частину площі сусідніх стіль- ників або на крайніх - зовнішні їхні площини, то у такому разі вважають, що це відповідає 0,5 вулички [2].

Для визначення сили сім'ї спочатку підраховували кількість вуличок, зайнятих бджолами. Помноживши одержану цифру на кількість бджіл, що відповідає одній вуличці, підрахуємо силу сім'ї.

Зимостійкість стану бджолиних сімей оцінювали на основі порівняння даних осінньої та весняної ревізій. Для цього використовували такі показники: кількість сімей, які загинули і втратили маток у кожній групі; кількість корму, який сім'я спожила у цілому і в перерахунку на одну вуличку бджіл, що перезимували; силу сімей після зимівлі [11].

Силу і кількість корму в гніздах визначали методом окремого зважування бджіл і стільників з кормом за допомогою ящика. Для цього визначали вагу ящика і вагу пустого стільника шляхом зважування 10 різновікових стільників і визначали їх середні ваги. Зважування проводили тільки у дні, несприятливі для льоту бджіл.

Закліщеність визначали перед обробкою і через 3 дні після обробки за допомогою Варроа-тестера. Обробку від кліща проводили препаратом Бипин-Т 23 вересня.

Оцінку миролюбності бджіл визначали за шкалою від 1 до 4, також можливі дробові оцінки з кроком 0,5

"4" - дуже миролюбні сім"ї, з якими працюють без захисного одягу і без димаря;

"3" - спокійні миролюбні сім'ї, де не потрібно захисного одягу, але потрібно трохи диму, також допускається поодинокі вжалення;

"2" - злобливі сім'ї, при роботі з якими потрібно використовувати захисний одяг і димар;

"1" - дуже злобливі сім'ї, бджоли яких постійно атакують, потрібно працювати в повному обмундируванні, і використовувати велику кількість диму.

Для визначення санітарної активності бджіл застосовували «голковий» тест. Голкою проколювали 100 комірок запечатаного розплоду. Стільник з ушкодженим розплодом повертали на місце в бджолосім'ю. Кількість повністю очищених комірок від пошкоджених личинок визначали через 12 і 24 години.

Статистичну обробку результатів досліджень проводили за допомогою програм Microsoft Excel та "Statistica 6.1" за Г.Ф. Лакиным [12]. Різницю між показниками вважали вірогідною при $\mathrm{P}<0,05\left(^{*}\right), \mathrm{P}<0,01\left(^{* *}\right), \mathrm{P}<0,001\left(^{* * *}\right)$.

Результати досліджень. Найбільшою загрозою сучасного бджільництва є варроатоз [3] . Однією з найважливіших помилок $€$ утримання так званих "кліщових бомб", тобто бджолосімей, генофонд яких збіднений щодо генів толерантності до Varroa. Розвиток розплоду в бджолиних сім'ях досягає в половині літа свого найвищого рівня. Якщо не проводити лікування, то в цей момент значно зростає ураження розплоду кліщами, що загрожує загибеллю сім'ї восени або взимку.

Найбільше ураження варротозом виявлено у бджіл контрольної групи, а найменше - у шостої. (табл.1). Втім, достовірна різниця за ураженістю бджіл кліщем між контрольною та дослідними групами була відмічена лише після їх обробки і вона становила між першою і другою групами 1,0 та першою і третьою - 1,1 шт./10 г. 
Таблиця 1

Оцінка варростійкості бджолосімей

\begin{tabular}{|c|c|c|c|c|c|c|c|}
\hline \multirow{2}{*}{ Група бджіл } & \multirow{2}{*}{ Кількість бджоло-сімей } & \multicolumn{3}{|c|}{ Перед обробкою } & \multicolumn{3}{c|}{ Після обробки } \\
\cline { 3 - 8 } & кількість кліща, шт./10 г & закліщеність, \% & Cv, \% & кількість кліща, шт/10 г & закліщеність, \% & Сv, \% \\
\hline I & 10 & $10,3 \pm 1,22$ & 3,4 & 35,6 & $2,0 \pm 0,33$ & 0,11 & 50,0 \\
\hline II & 11 & $9,6 \pm 0,64$ & 3,2 & 20,9 & $1,0 \pm 0,27^{*}$ & 0,09 & 85,3 \\
\hline III & 10 & $6,7 \pm 1,54$ & 2,2 & 72,5 & $0,9 \pm 0,23^{*}$ & 0,08 & 77,8 \\
\hline IV & 10 & $9,5 \pm 1,06$ & 3,2 & 33,4 & $1,8 \pm 0,25$ & 0,08 & 41,6 \\
\hline V & 10 & $8,8 \pm 1,12$ & 2,9 & 38,3 & $1,9 \pm 0,28$ & 0,09 & 43,7 \\
\hline VI & 10 & $8,7 \pm 0,79$ & 2,9 & 27,2 & $1,3 \pm 0,26$ & 0,09 & 60,1 \\
\hline
\end{tabular}

Примітка. Вірогідність різниці між показниками у цій і наступних таблицях вказана при порівнянні з I (контрольною) групою.

Захист від багатьох збудників хвороб медоносних бджіл забезпечує їх гігієнічна поведінка. Встановлено, що через 12 годин видалення пошкоджених личинок становило 69,7-76,3 \% (табл. 2). Найбільший відсоток видалення пошкоджених личинок спостерігався у бджіл другої групи, тобто у кросу $о$ мікропопуляція «915» х §ิ мікропопуляція «915». Найменше вичищених пошкоджених комірок відмічено у бджіл шостої групи - 69,7 \%, що вірогідно менше, ніж у бджіл контрольної групи на 4,6 \% (P<0,05).

Гігієнічні властивості бджолосімей різних генеалогічних груп

Таблиця 2

\begin{tabular}{|c|c|c|c|c|}
\hline \multirow{2}{*}{ Група бджіл } & \multicolumn{2}{|c|}{ Контроль очистки комірок, через 12 год, \% } & \multicolumn{2}{c|}{ Контроль очистки комірок, через 24 год, \% } \\
\cline { 2 - 5 } & $\mathrm{M} \pm \mathrm{m}$ & $5, \%$ & $\mathrm{M} \pm \mathrm{m}$ & $\mathrm{Cv}, \%$ \\
\hline I & $74,3 \pm 1,45$ & 6,6 & $91,0 \pm 0,59$ & 2,0 \\
\hline II & $76,3 \pm 1,73$ & 3,8 & $91,7 \pm 0,40$ & 1,3 \\
\hline III & $74,2 \pm 0,94$ & 5,5 & $92,5 \pm 0,40^{*}$ & 1,3 \\
\hline $\mathrm{V}$ & $76,1 \pm 1,40$ & 4,6 & $92,4 \pm 0,71$ & 2,3 \\
\hline $\mathrm{VI}$ & $72,9 \pm 1,12$ & $92,8 \pm 0,91$ & 2,9 \\
\hline
\end{tabular}

Результати оцінки очищення пошкоджених комірок через 24 години свідчать, що найкращий відсоток видалення пошкоджених личинок спостерігався у бджіл кросу q лінія «Тройзек 07» х §ิ мікропопуляція «915» - 92,8 \%, а найменший $(90,9 \%)$ - у кросу $\subsetneq$ мікропопуляція $\mathrm{G}$. Macha $\mathrm{x}$ ๙ мікропопуляція «915. Однак слід зазначити, що за вищенаведеним показником контрольну групу вірогідно переважали лише бджоли третьої групи і ця перевага становила
$1,5 \%(P<0,05)$.

Серед інших господарськи корисних ознак бджолиних сімей визначають їх зимостійкість [7]. Результати наших досліджень свідчать, що найбільш сильними перед зимівлею були бджолосім'ї інбредного кросу мікропопуляції «915» (друга група), а найслабшими - бджолосім'ї кросу G. Macha (шоста група) (табл. 3). Різниця між ними за цим показником становила 4854 особини $(P<0,05)$.

Таблиця 3

Стан бджолиних сімей перед зимівлею

\begin{tabular}{|c|c|c|c|c|c|}
\hline \multirow[b]{2}{*}{ Група бджіл } & \multirow{2}{*}{$\begin{array}{l}\text { Кількість бджоло- } \\
\text { сімей }\end{array}$} & \multicolumn{2}{|c|}{ Сила сім'ї, бджіл } & \multicolumn{2}{|c|}{ Кількість корму, кг } \\
\hline & & $\mathrm{M} \pm \mathrm{m}$ & $\mathrm{Cv}, \%$ & $\mathrm{M} \pm \mathrm{m}$ & $\mathrm{Cv}, \%$ \\
\hline I & 10 & $8584 \pm 1040$ & 24,2 & $14,3 \pm 1,81$ & 25,4 \\
\hline II & 11 & $10220 \pm 511$ & 7,1 & $17,7 \pm 0,43$ & 3,4 \\
\hline III & 10 & $9709 \pm 511$ & 7,4 & $17,3 \pm 0,43$ & 3,5 \\
\hline IV & 10 & $9965 \pm 443$ & 6,3 & $16,6 \pm 0,92$ & 7,9 \\
\hline V & 10 & $7154 \pm 1022$ & 20,2 & $12,2 \pm 1,47$ & 17 \\
\hline $\mathrm{Vl}$ & 10 & $5366 \pm 443^{*}$ & 11,7 & $9,1 \pm 0,61^{*}$ & 9,5 \\
\hline
\end{tabular}

Найбільше корму на зиму мали бджоли другої групи - 17,7 кг, що більше ніж у контрольної на 3,3 кг. За названим показником бджолосім'ї контрольної групи поступалися також особинам третьої - на 3,0 та четвертої групи - на 2,3 кг, однак переважали п'яту групу на 1,1 кг, втім в жодному 3 наведених випадків різниця не була вірогідною.

Миролюбність, а також посидючість на стільниках $€$ найбільш суб'єктивною ознакою поведінки бджіл. Так, якщо бджоли при огляді щільно сидять на рамках, не метушаться, то таку сім'ю можна називати миролюбною. Об'єктивну оцінку практичної селекції миролюбності бджіл може дати тільки пасічник, тому ставляться до цих ознак, як до суб'єктивних.

Встановлено, що бджоли підконтрольних кросів відрізнялися за поведінкою. Здебільшого бджоли підконтрольних груп були спокійні миролюбні і лише бджолосім'ї контрольної на четвертої груп були злобливі (табл.4).

Оцінка миролюбності бджіл

\begin{tabular}{|c|c|c|c|}
\hline Група бджіл & Кількість бджолосімей & $\mathrm{M} \pm \mathrm{m}$, бали & $\mathrm{Cv}, \%$ \\
\hline I & 10 & $2,2 \pm 0,83$ & 25,4 \\
\hline II & 11 & $3,7 \pm 0,17$ & 6,4 \\
\hline III & 10 & $3,8 \pm 0,17$ & 6,1 \\
\hline IV & 10 & $2,3 \pm 0,17$ & 10,1 \\
\hline V & 10 & $3,0 \pm 0,29$ & 13,6 \\
\hline
\end{tabular}


За миролюбністю бджоли контрольної групи поступалися бджолосім'ям другої на 1,5, третьої - на 1,6, четвертої - на 0,1, п'ятої - на 0,8 і шостої на - 1,1 бала.

За стійкістю до варроатозу кращими виявилися бджоли селекційного кросу ФUA3-65- 2019 x $\curvearrowright$ UA3-5- 915.112-2018. Найбільш сильними перед зимівлею були бджолосім'ї інбредного кросу мікропопуляції «915», а найслабшими - бджолосім'ї кросу G. Macha. Більшість кросів відносилися до спокійних миролюбних і лише бджолосім'ї місцевої карпатської популяції та кросу ОUА3-5- 35-2019 х §. UA3-5- 9-15.112-2018 відзначалися злобливістю.

Зимостійкість бджіл визначали шляхом порівняння даних осінньої весняної ревізій. Пасіка зимувала на дворі. Незважаючи не те, що протягом зими була аномальна температура $\left(0 \ldots+2^{\circ} \mathrm{C}\right)$ всі сім'ї перезимували добре, без втрат чи слідів поносу. У результаті проведених досліджень, встановлено, що загальна кількість витраченого корму становила, залежно від групи, 4,44-5,89 кг (табл. 5). При цьому найбільшу кількість корму спожили бджоли контрольної групи, а найменше - селекційного кросу q мікропопуляція G. Macha x ठ мікропопуляція «915». Різниця за названим показником між контрольною і дослідними групами коливалася від 0,25 до 1,45 кг, проте була достовірною лише між контрольною та шостою групами і становила 1,45 кг $(\mathrm{P}<0,01)$.

Таблиия 5

Оцінка зимостійкості бджолосімей $(\mathrm{n}=10)$

\begin{tabular}{|c|c|c|c|c|c|c|}
\hline \multirow{2}{*}{ Група бджіл } & \multicolumn{2}{|c|}{ Загальна кількість витраченого корму, кг } & \multicolumn{2}{|c|}{ Витрати корму на 1 кг бджіл } & \multicolumn{2}{c|}{ Відхід бджіл, кг } \\
\cline { 2 - 6 } & $\mathrm{M} \pm \mathrm{m}$ & $\mathrm{Cv}, \%$ & $\mathrm{M} \pm \mathrm{m}$ & $\mathrm{M} \pm \mathrm{m}$ \\
\hline $\mathrm{I}$ & $5,89 \pm 0,39$ & 20,1 & $4,20 \pm 0,22$ & 15,6 & $0,077 \pm 0,014$ \\
\hline II & $5,64 \pm 0,18$ & 9,6 & $4,09 \pm 0,22$ & 16,2 & $0,066 \pm 0,008$ \\
\hline III & $5,53 \pm 0,20$ & 10,7 & $3,70 \pm 0,20$ & 1,3 & $0,077 \pm 0,010$ \\
\hline IV & $5,58 \pm 0,32$ & 17,4 & $4,07 \pm 0,15$ & 11,0 & $0,081 \pm 0,002$ & 38,7 \\
\hline $\mathrm{V}$ & $5,00 \pm 0,18$ & 10,6 & $4,41 \pm 0,24$ & 16,3 & $0,069 \pm 0,004$ \\
\hline $\mathrm{VI}$ & $4,44 \pm 0,10^{* *}$ & 5,60 & $4,14 \pm 0,18$ & 8,19 & $0,078 \pm 0,005$ \\
\hline
\end{tabular}

Для більш точної оцінки використання кормів взимку вирахували їх витрату в розрахунку на 1 кг бджіл, що перезимували. Найменше значення цього показника відмічено у бджіл третьої групи - 3,70 кг, а найбільше - у бджолосімей п'ятої групи - 4,41 кг. Слід відмітити, що різниця між групами за витратою корму на 1 кг бджіл у жодному випадку не була вірогідною.

Результати наших досліджень свідчать, що впродовж зими бджолосім'ї не надто втратили силу. Відхід бджіл по всіх групах був в межах 0,066-0,081. При чому найменший цей показник відмічено у бджіл селекційного кросу $q$ мікропопуляція «915» х ठૈ мікропопуляція «915».

Висновки. 1. За стійкістю до варроатозу кращими виявилися бджоли селекційного кросу фUA3-65- 2019 х UA3-5- 9-15.112-2018.

2. Найбільш сильними перед зимівлею були бджоло- сім'ї інбредного кросу мікропопуляції «915», а найслабшими - бджолосім'ї кросу G. Macha. Більшість кросів відносилися до спокійних миролюбних і лише бджолосім'ї місцевої карпатської популяції та кросу оUA3-5- 35-2019 х ๙ UA3-5- 915.112-2018 відзначалися злобливістю.

3. Між бджолами різних внутрішньопородних кросів карпатської популяції спостерігалися певні відмінності за показниками відходу бджіл, загальних витрат кормів за зимівлю та в розрахунку на 1 кг бджіл. Найменше корму за зиму спожили бджолосім'ї шостої групи, проте в розрахунку на 1 кг бджіл найнижчі результати відмічені у бджіл третьої групи. Кращою зимостійкістю характеризувалися бджоли, отримані від поєднання самок і самців мікропопуляції «915», а гігієнічною поведінкою через 12 і 24 годин після пошкодження розплоду - бджолосім'ї другої і п'ятої груп відповідно.

\section{Список використаної літератури:} 2011. 19 c.

1. Бондарчук Г. Л. Становлення та розвиток бджільництва в Україні: автореф. Дис.. канд.. с.-г. наук: 06.04.01. Київ,

2. Броварський В., Бріндза В., Отченашко В., Повозніков М., Адамчук Л. Методика дослідної справи у бджільництві. Київ: Видавничий дім «Вініченко», 2017. 166 с.

3. Гайдар В. А., Папп В.В.Варомор - нищівний удар по вароатозу бджіл. Український пасічник.2012. № 2, С. 45-46

4. Гайдар В. А., Сахацький М. І., Папп В. В. Селекційно-племінна робота з карпатськими бджолами внутрішньопородного типу «Синевир»[Електронний ресурс]. Наукові доповіді НУБіП України Режим доступу до журн. http://archive.nbuv.gov.ua/e-journals/nd/2012_5/12smi.pdf. 2012. № 34. 11 c.

5. Гайдар В. А. Карпатська порода бджіл та її типи. Науковий вісник Національного аграрного університету. 2006. Вип. 94, С. 30-35.

6. Гайдар В.А. Пилипенко В.В. Три типи карпатських бджіл визнані як селекційне досягнення. Пасіка. 2010. № 3, С. 8-

9.

7. Данкевич В., Данкевич Є., Пивовар П. Формування кон'юнктури світового ринку меду: сучасний стан і перспективи для українських експортерів. Agricultural and Resource Economics: International Scientific E-Journal. 2018. Vol. 4. No. 2. Pp. 3754.

8. Керек С. С. Ефективність використання міжтипових гібридів карпатських бджіл. Науковий вісник Національного аграрного університету. 2006. № 4, С. $93-100$.

9. Керек С. С., Керек П. М. Особливості породної характеристики місцевих бджіл низинних районів Закарпатської області. Бджільництво України. 2017. Вип. 2, С. 115-128. 
10. Керек С. С., Керек П. М. Породна характеристика бджіл, що населяють райони закарпатської області з гористою місцевістю. Науково-виробничий журнал Бджільництво України. 2018. № 3, С.49-61.

11. Кондрюк А. Ф., Якубаш Н. О. Оцінка зимостійкості та продуктивності української породи бджіл різної селекції. Розведення і генетика тварин. 2008. Вип. 42, С. 108-114.

12. Лакин Г. Ф. Биометрия. М.: Высшая школа, 1990. 352 с.

13. Папп В. В., Гайдар В. А. Створення нового типу карпатських бджіл - «Синевир». Бджільництво. Міжвідомчий тематичний науковий збірник. 2010. № 44, С. 92-102.

14. Папп В. В., Керек С. С., Кейль Е.І. Карпатські бджоли типу Синевир. Бджільництво України.2015. № 1, С. 158-165.

15. Папп В. В., Кізман-байза А. А., Плиска В. М. Оцінка простих міжтипових гібридів карпатських бджіл в парі поєднань Синевир та Вучківського. Бджільництво України. 2017. № 2, С. 158-165.

16. Шамро М. О. Спосіб контролю стану бджолиної сімї у вулику під час зимівлі: Деклараційний патент на корисну модель UA 15806U; МПК А01К 47/06. 2006.01.

\section{References:}

1. Bondarchuk H. L. 2011. Stanovlennia ta rozvytok bdzhilnytstva v Ukraini: avtoref. Dys.. kand.. s.-h. nauk: 06.04.01. Kyiv, 2011. 19 s. [Formation and development of beekeeping in Ukraine]: Abstract of Ph.D. dissertation, Kyiv.

2. Brovarskyi V., Brindza V., Otchenashko V., Povoznikov M. and Adamchuk L. 2017. Kyiv: Metodyka doslidnoi spravy u bdzhilnytstvi [Methods of research in beekeeping]. Kyiv: "Vinichenko" Publishing House.

3. Haidar V. A. and Papp V. V. 2012. Varomor - nyshchivnyi udar po varoatozu bdzhil [Varomor is a devastating blow to bee varroatosis]. Ukrainskyi pasichnyk. № 2, pp. 45-46.

4. Haidar V. A., Sakhatskyi M. I. and Papp V. V. 2012. Selektsiino-pleminna robota z karpatskymy bdzholamy vnutrishnoporodnoho typu «Synevyr» [Selection and breeding work with Carpathian bees of interbreed type "Synevyr]; Naukovi dopovidi NUBiP Ukrainy. No 34, p.11. [Electronic resource]. Rezhym dostup: http://archive.nbuv.gov.ua/e-journals/nd/2012_5/12smi.pdf. 2012. № 34. $11 \mathrm{C}$.

5. Haidar V. A. 2006. Karpatska poroda bdzhil ta yii typy. [Carpathian breed of bees and its types]. Naukovyi visnyk Natsionalnoho ahrarnoho universytetu. Issue 94, pp. 30-35.

6. Haidar V.A. and Pylypenko V.V. 2010. Try typy karpatskykh bdzhil vyznani yak selektsiine dosiahnennia. [Three types of Carpathian bees are recognized as a selection achievement]. Pasika. no 3, pp. 8-9.

7 Dankevych V., Dankevych Ye. And Pyvovar P. 2018. Formuvannia koniunktury svitovoho rynku medu: suchasnyi stan i perspektyvy dlia ukrainskykh eksporteriv [Forming conjuncture in the world honey market: current state and prospects for Ukrainian exporters]. Agriculturaland Resource Economics: International Scientific E-Journal. vol. 4., no. 2., pp. 37-54

8. Kerek S. S. 2006. Efektyvnist vykorystannia mizhtypovykh hibrydiv karpatskykh bdzhil [Efficiency of using intertype hybrids of Carpathian bees]. Naukovyi visnyk Natsionalnoho ahrarnoho universytetu, no 4, pp. 93-100.

9. Kerek S. S. and Kerek P. M., 2017. Osoblyvosti porodnoi kharakterystyky mistsevykh bdzhil nyzynnykh raioniv Zakarpatskoi oblasti [Peculiarities of breed characteristics of native beesfrom lowland areasof transcarpathia]. Bdzhilnytstvo Ukrainy, no 2, pp. 115-128.

10. Kerek S. S. and Kerek P. M., 2018. Porodna kharakterystyka bdzhil, shcho naseliaiut raiony zakarpatskoi oblasti z horystoiu mistsevistiu [The breed characteristic of bees inhabiting areas of the trans carpathian region with mountain ousterrain]. Bdzhilnytstvo Ukrainy, no 3, pp. 49-61.

11. Kondriuk A. F. and Yakubash N. O., 2008. Otsinka zymostiikosti ta produktyvnosti ukrainskoi porody bdzhil riznoi selektsii [Estimation of winter hardiness and productivity of the Ukrainian breed of bees of different selection]. Rozvedennia $i$ henetyka tvaryn, issue 42, pp. 108-114.

12. Lakyn H. F., 1990. Byometryia [Biometrics]. M.: Vysshaia shkola

13. Papp V. V. and Haidar V. A. 2010. Stvorennia novoho typu karpatskykh bdzhil - «Synevyr» [Creation of a new type of Carpathian bees - "Synevyr"]. Bdzhilnytstvo, no 44, pp. 92-102.

14. Papp V. V., Kerek S. S. and Keil E. I. 2015. Karpatski bdzholy typu Synevyr [Carpathian bees of Synevyr type]. Bdzhilnytstvo Ukrainy, no 1, pp. 158-165.

15. Papp V. V., Kizman-baiza A. A. and Plyska V. M., 2017. Otsinka prostykh mizhtypovykh hibrydiv karpatskykh bdzhil v pari poiednan Synevyr ta Vuchkivskoho [Assessment of simple intertypicalhybrids of carpathian bees paired combinations of Synevyr and Vuchkivskij types]. Bdzhilnytstvo Ukrainy, no 2, pp. 158-165.

16. Shamro M. O., 2006. Sposib kontroliu stanu bdzholynoi simi u vulyku pid chas zymivli: Deklaratsiinyi patent na korysnu model [The method of monitoring the condition of the bee family in the hive during the winter: Declarative patent for a utility model]. UA 15806U; MPK A01K 47/06. 2006.01.

NAAS

Fedorovych Vitaliy Vasylyovych, doctor of Science in Agriculture, Senior Research Fellow, Institute of Animal Biology

Petko Mariya Serhiyvna, graduate student, Institute of Animal Breeding and Genetics nd. a. M.V.Zubets of NAAS

Chornyi Ihor Oleksandrovych, assistant, State agrarian and engineering University in Podillia

Mazur Nataliya Petrivna, doctor of Science in Agriculture, Institute of Animal Biology NAAS

Economic useful features of different genealogical bee formations of the carpathian breed

Among the factors that determine the progress of mankind, a significant place belongs to selection of breeding and produc- 
tive qualities of bees. Opportunities to increase productivity and the viability of bee colonies by improving their hereditary traits depends on learning of the evolution and biology of bees. In this case, it should be noted that an important role in improving the productivity of apiaries is the use of interbreed and interlinear hybrids. In view of the above, the purpose of the study was to evaluate peacefulness, varroatosis resistance, strength, winter hardiness and hygienic properties of bee families of different intra-linear crosses of the Carpathian bee population. Studies have been conducted on bees of various genealogical formations of the Carpathian breeds in private apiaries in the village Navariya and Brody town in Lviv region. For experimental studies, 6 groups of 10 bee families in each were formed: I - control group - local bees of the Carpathian population (type "Vuchkivska" - 10 bee families); II - experi-

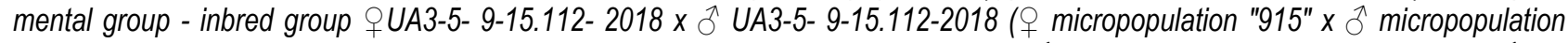

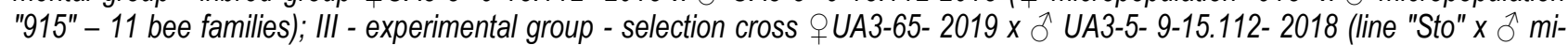
cropopulation "915" - 10 bee families; IV - research group - selection cross + UA3-5- 35-2019 x §ิ UA3-5- 9-15.112-2018 (P Vuchkivska $x$ ○े micropopulation "915" - 10 bee families); $V$ - experimental group - selection cross $\bigcirc$ AE99- 307 / 67- 2018 x § UA3-5- 915.112-2018 (Q line "Troisek 07" x § micropopulation "915" - 10 bee families); VI - experimental group - selection cross $\bigcirc \mathrm{G}$. Macha

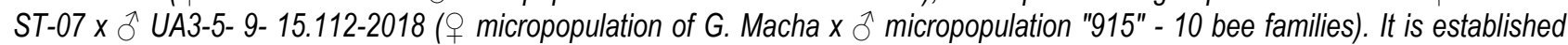
that between bees of different intrabreed crosses of the Carpathian population there were some differences in bee lost rates, total costs feed for the winter and per $1 \mathrm{~kg}$ of bees. The least food for the winter was consumed by bee families of the sixth group, but per $1 \mathrm{~kg}$ of bees the lowest results were observed in bees of the third group. The best winter hardiness was characterized by bees obtained from combination of females and males of the micropopulation "915", and by hygienic behavior after 12 and 24 hours after brood damage - bee colonies of the second and fifth groups, respectively. By resistance to varroatosis were the best bees breeding cross o UA3-65- 2019 x ô UA3-5- 9-15.112-2018. Inbred cross micropopulation "915" bee families were the strongest before winter and the weakest - cross $G$. Macha bee families. Most crosses belonged to the quiet peaceful and only bee families of the local Carpathian population and cross + UA3-5- 35-2019 x ठิ UA3-5- 9-15.112-2018 were marked by malevolence.

Key words: Carpathian bee breed, interlinear crosses, varroatosis resistance, hygienic behavior, strength of bee colonies, peacefulness of bees, winter hardiness of bee families.

Дата надходження до редакції: 15.10.2020 р. 